\title{
Population of Thrips sp. on the Integrated Pest Management and Conventional farming on Chilli (Capsicum annuum L.) at Bayem Village, Sub-District Kasembon, Malang
}

\author{
Bachtiar Rachmad Sugiyono ${ }^{1 *}$, Gatot Mudjiono², Rina Rachmawati² \\ ${ }^{1}$ Graduate of Faculty of Agriculture, University of Brawijaya \\ ${ }^{2}$ Departement of Plant Protection, Faculty of Agriculture, University of Brawijaya
}

\begin{abstract}
This research aimed to find out an abundance of Thrips sp. population on Integrated Pest Management (IPM) and conventional farming at chilli plantation. The research was conducted on August until November 2012 at the Bayem Village, Sub-distric Kasembon, Malang, East Java and Entomology Laboratory, Departement of Plant Protection, Agriculture Faculty, Brawijaya University. The methods to determine abundance population Thrips sp. was using quadrant with 4 plants samples in 1 beds were taken. The observation was using 16 plants, on the each treatment of IPM and conventional farming. The result showed that the population of Thrips sp. (nymph) on IPM and conventional was not significantly different, while the population of Thrips sp. (adult) in the IPM treatment was significantly higher compared to conventional. Plant height on IPM treatment was higher than conventional treatment. The statistical analysis on Thrips sp. attacks indicated, that the intensity of damage on IPM treatment $(0.16 \%)$ and conventional treatment $(0,14 \%)$ were not significantly different. The yield of chilli on the IPM (31\%) was significantly higher than compared to conventional treatment. Chilli cultivation costs on IPM was higher $(2.5 \%)$ rather than the conventional. The yield of chilli plant per hectare on IPM had advantage higher (37\%) than conventional. The calculation of the BCR at the IPM was higher (27\%) than the conventional farming.
\end{abstract}

Key words: Abundance, analysis of farming, IPM, Thrips sp.

\section{INTRODUCTION}

Chilli (Capsicum annuum L.) is a vegetable commodity that has a high economic value. Chilli needs continue to increase every year in line with the increasing number of population and the development of industries that require raw materials of chilli [1]. The productivity of chilli can be reduced due to pest disturbance.

Main pest on the chilli is Thrips sp. (Thysanoptera: Thripidae), which could made crop losses of up to $23 \%$. The attacks that occur at the beginning of planting can be very damaging and it will allowing the occurrence of dwarfing, plants wither, and dead plants [2]. In control of Thrips sp., Farmers are using various of pesticides and it have a negative impact such as reducing the abundance of natural enemies in chilli. To mitigate the negative impacts, an agroecosystem management by using Integrated Pest Management (IPM) on the field is required. IPM is an ecosystem-based strategy that focuses on long-term prevention of pests or their damage through a combination of techniques such as biological control, habitat manipulation, modification of cultural practices, and use of resistant varieties. Pesticides are used only after monitoring indicates they are needed according to established guidelines and treatments are made with the goal of removing only the target organism [3]. The implementation and development of IPM will not work without sufficient and continuous support from the research program. The application of polyculture in the IPM will be able to present the fauna diversity that will also increase diversity of natural enemies. That polyculture is combining several commodities, which has the potential to create a diversity of fauna with a more complex of food frames including to stimulate the presence of biological controls [4].

Implementation of appropriate IPM on chilli cultivation is expected to decrease the population and intensity of Thrips sp. Therefore, the use of pesticides can be reduced. The application of IPM is expected to improve the quality and quantity yield of chilli, so that the economic value is increased.

This research aimed to determine the effect of IPM and conventional farming on large chilli cultivations on the Thrips sp population abundance at Bayem Village, Kasembon Subdistrict, Malang. 


\section{MATERIAL AND METHOD}

The materials used in this study were big chilli variety of Gada MK, peanuts, silver black plastic mulch, compost tea, cartel soil, manure, Plant Growth Promoting Rhizobacteria (PGPR), which is consist of fungi Trichoderma sp., Pseudomonas flourescent Migula, Basillus subtilis Chon, Acetobacter sp., and Azospirillum sp. PGPR have some functions, such as: a) able to spur the growth and physiology of the roots and able to reduce disease damage by insects; b) Increasing availability of other nutrients such as phosphate, sulfur, iron and copper; c) PGPR can produce plant hormones, adding bacteria and fungi that can control pests and diseases. Midec also being used, it was developed by Department of Plant Protection, Faculty of Agriculture, University of Brawijaya which consist of fungi Trichoderma sp., Aspergillus niger van Tienghem, Saccharromyces sp., and bacteria $P$. flourescent, $B$. subtilis. Midec have some functions, such as: a) it can be used to deal with plant damage problems caused by pathogens; b) Maintaining the structure of plant cells and cell mobility in plants. The others materials that were used in this research consist of: NPK "Mutiara" 16:16:16, foliar fertilizer "Vitabloon", “Phonska" 15:15:15, organic fertilizer Mikoriza "Kusuma Bioplus". Chemical pestiside "Alika 247 ZC" with material active lamda sihalotrin $106 \mathrm{gr} / \mathrm{L}$ and tiametoksam 141 $\mathrm{gr} / \mathrm{L}$ and biopesticide "Organeem" with material active azadirachtin 0,8-1,4\%.

\section{Methodology}

The research were using two block field treatments, consist of: 1) The chilli field with IPM and 2) The conventional farming that were using by the farmers. The data observations were population Thrips sp., pest attacks frequency on chilli, data analysis, yield calculations, and farming analysis. The research method is described as follows:

\section{a. Chilli field}

In this study chilli cultivation is divided into two treatments, namely IPM and conventional by farmers. Each experimental plots was $210 \mathrm{~m}^{2}$

b. Observation Thrips sp. population and the frequency of attacks on chilli

Observation of Thrips sp. population abundance in chilli plant is a fixed observation. Observation aimed to determine the population abundance of Thrips sp. On a fixed sample plot. The quadrant method used to find out the population abundance of Thrips $\mathrm{sp}$ with 4 plant samples in 1 beds, starting at the second beds and the next beds. Observation population Thrips $\mathrm{sp}$ at 4 day intervals. Identification of Thrips sp. was done by using an insect identification book [5]. It was purposed to know the species of Thrips $s p$ that exist in the chilli. Analysis of plant growth were including plant height, number of leaves, and number of leaves attacked by Thrips sp. The formula used to determine the the attack intensity is:

$$
\mathrm{P}=\frac{a}{N} x 100 \%
$$

Description: $P=$ the rate of plant damage to the plant (\%), $a$ is the number of leaves, stems, flowers, fruits affected per plant sample, $\mathrm{N}$ is the number of leaves, stems, flowers, fruit observed per plant sample.

\section{c. Analysis Data}

Population Thrips sp. and attack intensity on chilli in the IPM and conventional farming were statistically analyzed by using $\mathrm{T}$ test with $5 \%$ level.

d. Yield

Calculation of average yield was calculated by the number of crops with 32 plant samples, the formula used is as follows:

Average $=\frac{\text { harvest } 1+\text { harvest } 2+\cdots+\text { harvest } n}{n}$

Description: $\mathrm{n}=$ total of harvest time

e. Analysis Farming

Analysis of the farming aimed to calculate the feasibility of chilli cultivation in IPM and conventional treatment. This can be discussed in the analysis below:

\section{- Variable costs}

Variable costs are costs that change in proportion to the plant needs. The higher farming activities will make the higher variable cost, the less farming activities will make the lower amount of variable costs.

\section{- Total revenue}

Analysis of farming system aims to know the profits derived from the farm business. To calculate income can be used formula as below:

$$
\mathbf{T R}=\mathbf{P} \times \mathbf{Q}
$$

\section{Descriptions:}

$\mathrm{TR}=$ Total Revenue

$\mathrm{P}=$ Price (the cost per $\mathrm{Kg}$ )

$Q=$ Quantity (the number of products)

- Profit

Profit is the difference between income and expenses related to business activities. Profit $(\pi)$ 
Is the result of subtraction (Income) with total (Cost). The formula:

$\pi=\mathrm{I}-\mathrm{C}$

\section{- Break Event Point (BEP)}

Break Event Point (BEP) is the point at which total cost and total revenue are equal. Therefore, the point will be used to decide the profitable farming system. Break event point calculation by using formula could be done in the two types, that consist of break event point of production and break event point price.

a. Break Event Point (BEP) production

BEP unit Total Cost of Production (TC) / Price (P)

b. Break Event Point (BEP) Price BEP Price is Total Cost Production (TC) / Quantity of products (Q)

- Benefit Cost Ratio (BCR)

Benefit Cost Ratio (BCR) is a measure of the comparison between income and cost. $B C R$ is calculated to determine the feasibility of a business. BCR> 1 means that the business is feasible. The formula $B C R$ is the total revenue divided by the total cost of production. The formula is:

Benefit Cost Ratio $=$ Total Revenue $/$ total cost

\section{Data Collection}

Explain the data collection methods, i.e. surveys, observations or archive, accompanied by details of the use of such methods. This section also describes the population, sampling and sample selection methods.

he use of English language should followed proper grammar and terms. Name of organism shoul be followed by its full scientific name in the first mention, in italic [3]. Author of the scientific name and the word of "var." typed regular. Example: Stellaria saxatillis Buch. Ham. First abbreviation typed in colon after the abbreviated phrase.

Author must use International Standard Unit (SI). Negative exponent used to show the denominator unit. Example: $\mathrm{g} \mathrm{l}^{-1}$, instead of $\mathrm{g} / \mathrm{l}$. The unit spaced after the numbers, except percentage [4]. Example: $25 \mathrm{~g} \mathrm{l}^{-1}$, instead of $25 \mathrm{gl}^{-}$ 1 ; $35 \%$ instead of $35 \%$. Decimal typed in dot (not coma). All tables and figures should be mentioned in the text.

\section{RESULT AND DISCUSSION}

The observations population of Thrips sp. were found various life phases of these pests, both in nymph and imago phase in the treatment of IPM and conventional.

Based on statistical analysis, the mean value of nymph population in IPM and conventional treatment was not significantly different. While the mean value of the imago population in the IPM treatment was significantly higher than in the conventional treatment.

Observation of nymph population of Thrips sp. on the IPM and conventional were conducted at 7 DAP to 83 DAP. During the observation in that time there is often a fluctuation in the number of nymph population. The largest number of nymphs population in the treatment of IPM at 39 DAP and 47 DAP (Fig. 1)., symptom attacks by Thrips sp. (nymph) were characterized with shriveled leaves, plants becoming dwarfed, and it happens in the flowering times [6]. In the conventional treatment the highest nymph population were at 59 DAP, after that the population were decreased.

Table 1. Average population of Thrips sp. on Chili Plant on Integrated Pest Management and Convetional per Sample Plant at Bayam Village, Sub - District Kasembon.

\begin{tabular}{ccc}
\hline Thrips sp. Phase & $\begin{array}{l}\text { Nimfa } \\
\text { Population }\end{array}$ & $\begin{array}{l}\text { Imago } \\
\text { Population }\end{array}$ \\
\hline IPM & $0.85 \mathrm{a}$ & $3.05 \mathrm{~b}$ \\
Conventional & $0.24 \mathrm{a}$ & $1.39 \mathrm{a}$ \\
\hline
\end{tabular}

Description : Means of chilli plant height on IPM and conventional treatment which followed by different letter at the same column showed a significant difference based on $\mathrm{T}$ test at level $5 \%$

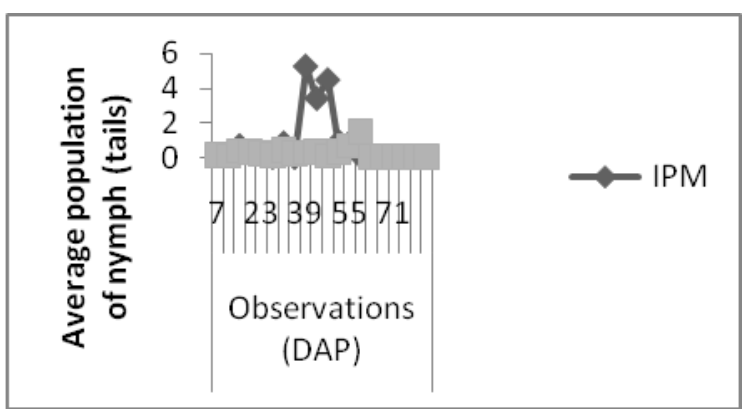

Figure 1. Population nymph fluctuation of Thrips sp. on IPM and conventional farming in Bayem Village, SubDistrict Kasembon.

The largest number of imago populations in IPM treatment at 43 DAP (Figure 4). The largest number of imago population occured, when chilli were entering the generative phase, when leaves, flowers, and fruit of chilli were still young. Population imago of Thrips sp. found higher in 
the flowers of chilli than in the other plant organs [7]. In the IPM treatment observation at 47 DAP showed a decreased population imago of Thrips sp. until 63 DAP. It caused by the application of biopesticide. Application of biopesticide on IPM treatment was conducted at 19 DAP and 43 DAP. The biopesticide contains active materials such as azadirachtin salts. Azadirachtin can be found in the seeds and leaves of the Mimba tree (Azadirachta indica). The azadirachtin is one of the triterpenoid secondary metabolites, that has been used as an active ingredient on biopesticides and proven to control more than 300 species of pests [8].

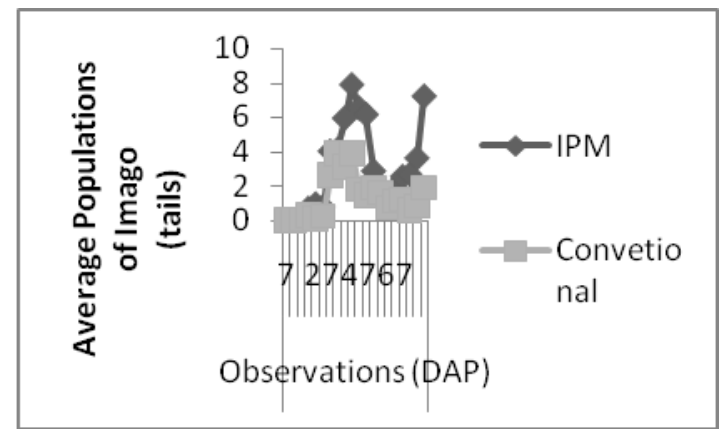

Figure 2. Population imago of Thrips sp on IPM and conventional farming in Bayem Village, Sub-District Kasembon.

In the treatment of IPM population imago of Thrips sp. increased from 67 DAP to 83 DAP. It could be happened because the population of imago Thrips sp. attack on the petals and flowers. In the conventional farming, population imago of Thrips sp. were inthe highest peak at 35 DAP and 43 DAP. In this phase, adult / imago of Thrips sp. were attacking on young leaves. The population imago of Thrips sp. mostly could be found in the young flowers and fruits. In the conventional treatment at 47 DAP imago population were decreased [9]. The highest number of imago populations was in the IPM treatment at 43 DAP, but at 47 until 63 DAP population imago Thrips sp were decreased. Then it was increased again at 67 DAP until 83 DAP.

\section{Growth Parameter}

The results of growth parameter was performed to find out the average growth of chilli on the treatment of IPM compared with conventional farming (Table 2).

The means of plant height in the IPM was significantly higher than that of conventional farming (Table 1). This suggests that the application of compost fertilizer to IPM treatment makes the plant better than not using compost in conventional treatment. The content of Nitrogen $(\mathrm{N})$ elements in compost fertilizer is required for the formation of vegetative parts. The application of compost fertilizer could increase the growth of chilli better than the treatment without using compost [10].

Table 2. Plant height $(\mathrm{cm})$ caused by Thrips sp. on IPM and conventional treatment in Bayem Village, SubDistrict Kasembon.

\begin{tabular}{cc}
\hline Treatment & Plant height $(\mathrm{cm})$ \\
\hline IPM & $37,4 \mathrm{~b}$ \\
Conventional & $36,3 \mathrm{a}$ \\
\hline
\end{tabular}

Description : Means of chilli plant height on IPM and conventional treatment which followed by different letter at the same column showed a significant difference based on $\mathrm{T}$ test at level $5 \%$

\section{Damage intensity}

The analysis of Thrips sp. showed that the damage intensity in the IPM and conventional treatment was not significantly different (Table 5).

Table 3. Damage intensity caused by Thrips sp. on IPM and conventional treatment in Bayem Village, Sub-District Kasembon.

\begin{tabular}{cc}
\hline Treatment & Damage intensity (\%) \\
\hline PHT & $0,16 \mathrm{a}$ \\
Conventional & $0,14 \mathrm{a}$ \\
\hline
\end{tabular}

Description : Means of chilli plant height on IPM and conventional treatment which followed by same letter at the same column showed no significant difference based on $\mathrm{T}$ test at level $5 \%$

The damage intensity were low on the IPM and conventional treatment, due to the plants were tolerant to Thrips sp (Table 4). The tolerant resistance mechanism occurs because of the ability of certain plants to recover from injuries due to pest attacks or able to recover faster, so that damage intensity from the pest are less affected the chilli, compared to the other plants that more sensitive [11].

\section{Yield}

The result of statistical analysis on the yield of chilli on IPM is significantly higher than that of chilli plants in conventional treatment.

\begin{tabular}{cc}
$\begin{array}{c}\text { Table 4. Yield of chilli (Kg) on IPM and conventional } \\
\text { treatment in Bayem Village, Sub District } \\
\text { Kasembon }\end{array}$ & Yield (Kg) \\
\hline Treatment & $8,5 \mathrm{~b}$ \\
IPM & $4,6 \mathrm{a}$ \\
\hline Conventional
\end{tabular}

Description : Means of chilli plant height on IPM and conventional treatment which followed by different letter 
at the same column showed a significant difference based on $\mathrm{T}$ test at level $5 \%$.

Although the population of Thrips sp. in the IPM is higher than conventional treatment, but the yield of chilli was still higher in IPM than conventional (Table 3). This proves that the IPM treatment provides compensation, i.e the plant is able to tolerate or compensate for the damage [12], and made optimum yield even though the plant is attacked by pests.

The yield on chilli cultivation in the IPM and conventional were high and low. It was due to pest and disease attack. One of the disease that cause the decline in the yield of chilli was the fruit rot or antranoksa. In the observation, antranoksa attacked chilli in the IPM were higher than conventional treatment. Antranoksa is one of the main diseases in chilli cultivation, especially in hot and humid tropical regions and it is also known as main diaseases at pre-harvest and post-harvest time. This disease can reduce quality of chilli and reduce production by $45-60 \%$ [13].

\section{Analysis of farming}

The business analysis contains an overview of the cost components to be incurred and the level of profit or loss rate obtained. By using proper cultivation strategy, production costs will be more efficient. The analysis of farming on chilli cultivation in IPM and conventional treatment is equalized to the extent of 1 hectare at each planting season. In this research, chilli cultivation treatment using plant spacing $60 \times 50 \mathrm{~cm}$ so that the plant population obtained 18,857 plants in one hectare.

Table 5. Analysis of chilli farming on IPM and conventional treatment at Bayem Village, Sub District Kasembon in 1 hectare.

\begin{tabular}{|c|c|c|}
\hline $\begin{array}{c}\text { Component } \\
\text { (per } \\
\text { hectare) }\end{array}$ & IPM & Conventional \\
\hline Variable cost & Rp. 18.741 .900 & Rp. 18.011.400 \\
\hline Fertilizer & Rp. 9.520 .000 & Rp. 4.576 .000 \\
\hline Pesticides & Rp. 1.914 .000 & Rp. 6.580 .000 \\
\hline Labor costs & Rp. 8.375.000 & Rp. 7.535.000 \\
\hline Total cost per & & \\
\hline planting season & Rp. 38.550 .000 & Rp. 36.702 .400 \\
\hline Income & Rp. 225.406 .300 & Rp. 122.573 .900 \\
\hline Profit & Rp. 186.885 .900 & Rp. 85.871.500 \\
\hline \multicolumn{3}{|l|}{ Break Event } \\
\hline \multicolumn{3}{|l|}{ Point (BEP) } \\
\hline BEP production & $7.710,08 \mathrm{Kg}$ & $7.340,48 \mathrm{Kg}$ \\
\hline BEP price & Rp. 855/Kg & Rp. $1.471 / \mathrm{Kg}$ \\
\hline $\begin{array}{l}\text { Benefit Cost } \\
\text { Ratio (BCR) }\end{array}$ & 5,85 & 3,34 \\
\hline
\end{tabular}

The cost of Chilli cultivation at IPM treatment is higher ( $R p 38,550,000)$ than conventional treatment ( $R p 36,702,400)$, but in the practice of chilli cultivation per hectare in IPM treatment has higher profit ( $\operatorname{Rp~186,885,900/planting~season)~}$ than in conventional ( $R p$ 85.871.500/planting season).

The result of analysis shows that the value of Break Event Point (BEP) of chilli on IPM treatment was $7,710,08 \mathrm{Kg} /$ planting season, for the BEP production was at the price level Rp. $885 / \mathrm{Kg}$. While in the conventional treatment shows that the yield of chilli production were $7,340.48 \mathrm{Kg} /$ planting season for BEP production, and BEP chilli business at the price level Rp. $1.471 / \mathrm{Kg}$. This values indicated that the chilli business was not on profit or loss at the price level of Rp. $885 / \mathrm{Kg}$ for IPM treatment, whereas in the conventional treatment would be at the price level of Rp. $1.471 / \mathrm{Kg}$.

Benefit Cost Ratio (BCR) is an analysis, that needed to compare income and cost of chilli cultivation. The BCR result showed at IPT were having the resultant profit about 5,85 times from capital gained. While in the conventional treatment, the profit generated 3.34 times the capital gained. This proves that the chilli cultivation by IPM is recommended to be applied.

\section{CONCLUSIONS}

Total population nymph of Thrips $\mathrm{sp}$ was not significantly different between IPM and conventional, while the number of imago population in IPM was higher than conventional treatment. Plant height in IPM was higher than conventional treatment. Intensity of Thrips sp on the IPM and conventional treatment was not significantly different.

The application of IPM on the chilli will become tolerant to Thrips sp attack, but it still could produce optimal production. The yield analysis result showed that yield of chilli on IPM were higher than conventional treatment. The calculation of $B C R$, showed the profits generated at the IPM were higher (5.85 times that of the obtained capital) than conventional treatment (3.34 times the capital gained).

\section{REFERENCES}

[1]. Subagyono, Kasdi. 2010. Budidaya dan Pascapanen Cabai Merah (Capsicum annuum L.). Balai Pengkajian Teknologi Pertanian, Jawa Tengah. 
[2]. Pitijo, S. 2003. Seri Penangkaran Benih Cabai. Kanisius. Yogyakarta

[3]. Oka, I.N. 1995. Pengendalian Hama Terpadu dan Implementasinya di Indonesia. Gajah Mada University Press. Yogyakarta.

[4]. Altieri, A.A. and C.I. Nicholls. 2004. Biodiversity and Pest Management in Agroecosystems, Food Products Press. New York. Hal 236.

[5]. Borror, D. J. dan D. M. De Long. 1970. An Introduction to The Study of Insects. Holt, Rinehart and Winston, New York, Chicago, San Francisco, Atlanta, Dallas, Montreal, Toronto, London, Sydney. 1029h.

[6]. Indiati, W. S. 2004. Penyaringan dan Mekanisme Ketahanan Kacang Hijau MLG716 Terhadap Hama Thrips. Jurnal Litbang Pertanian Vol. 23 No. 3 Tahun 2004 : Hal 101.

[7]. Higgins, C. J. 1992. 'Western Flower Thrips (Thysanoptera : Thripidae) in Greenhouse : Population Dynamics, Distribution on Plant and Assositation with Predators', J. Econ. Entomol. Vol. 85, pp. 1891 - 1993.

[8]. Samsudin, 2008. Azadirachtin Metabolit Sekunder dari Tanaman Mimba sebagai Bahan Insektisida Botani. Diunduh dari http://pertaniansehat.or.id/ index.php?pilih=news\&mod=yes\&aksi=lihat \&id=73. Diakses pada tanggal 17 Mei 2013.

[9]. Yamaguchi, T. 2007. 'Seasonal prevelence of Scirtothrips dorsalis Hood and Selonothrips rubrocinctus (Giard) on flower bud, inflorencences and fruits of manggo (Mangifera Indica) plants cultivated in greenhouse on Amani-Oshima Island, Japan', Kyusu PL Prot. Res., Vol. 53, pp. 10306.

[10]. Harahap, A. O. 2010. Pemanfaatan Kompos Tandan Kosong Kelapa Sawit dan Konsentrat Limbah Cair Pabrik Kelapa Sawit Untuk Memperbaiki Sifat Kimia Media Tanam Sub Soil Ultisol dan Pertumbuhan Bibit Kelapa Sawit (Elaeis guineensis Jacq.). Skripsi. Universitas Sumatra Utara, Sumatra Utara.

[11]. Untung, K. 2006. Pengantar Pengelolaan Hama Terpadu. Andi Offset. Yogyakarta.

[12]. Rauf, A. 1992. Penarikan Contoh dan Ambang Kendali Untuk Pengembangan PHT Kedelai. Diakses dari http://www.pustaka.litbang.deptan.go.id pada tanggal 2 Oktober 2013

[13]. Hidayat, I. M., Sulastrini, I., Kusandriani, Y. dan Permadi, A. H., 2004. Lesio Sebagai
Komponen Tanggap Buah 20 Galur dan atau Varietas Cabai Terhadap Inokulasi Collectrotichum capsici dan Collectrotichum gloeosporioides. Jurnal Hortkultura Vol. 14 No. 3 2004: 161-162. 